\title{
‡USGS
}

science for a changing world

Prepared for the National Aeronautics and Space Administration

\section{Geologic Map of the MTM 85200 Quadrangle, Olympia Rupēs Region of Mars}

By James A. Skinner, Jr., and Kenneth E. Herkenhoff

Pamphlet to accompany

Scientific Investigations Map 3197

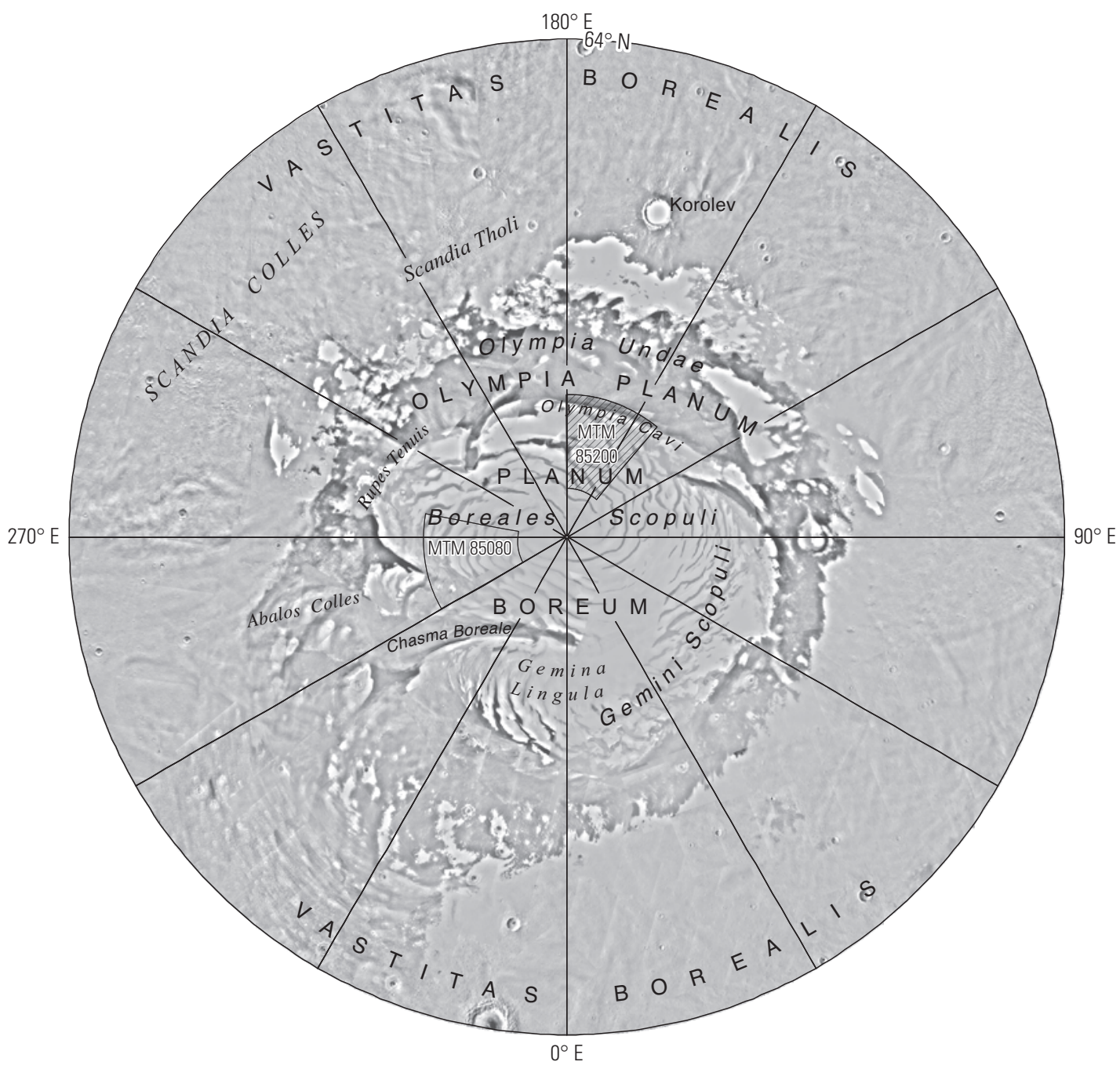

2012

U.S. Department of the Interior

U.S. Geological Survey 
This page intentionally left blank 


\section{Contents}

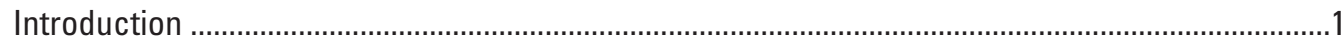

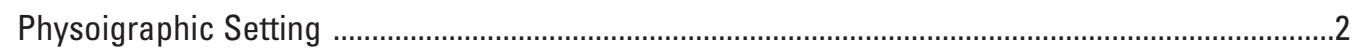

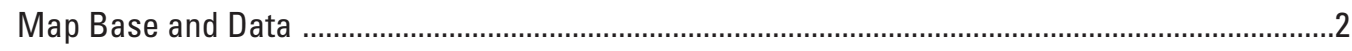

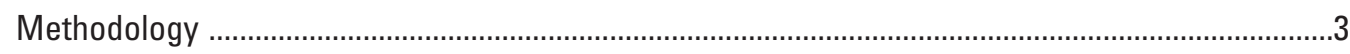

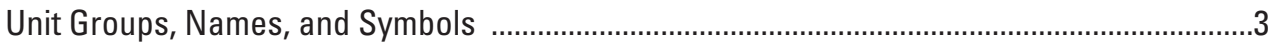

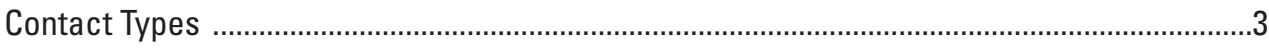

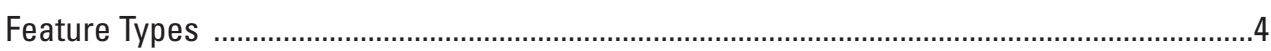

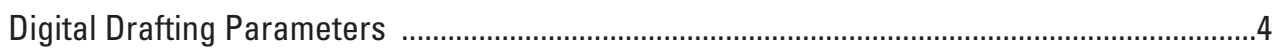

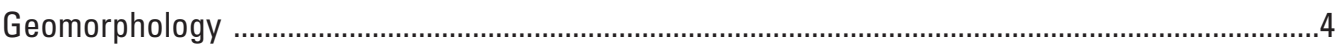

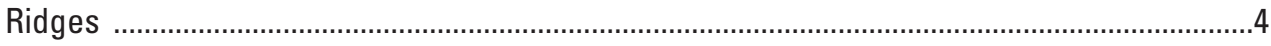

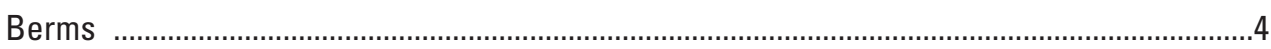

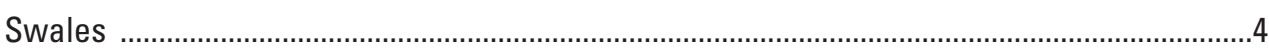

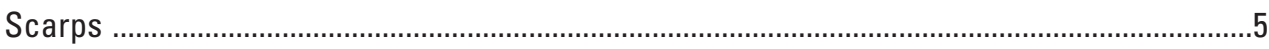

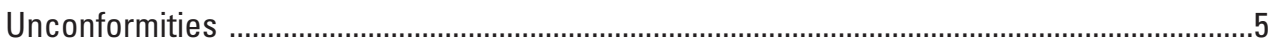

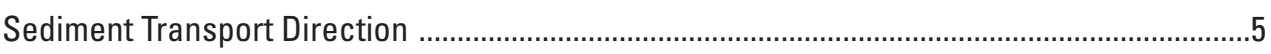

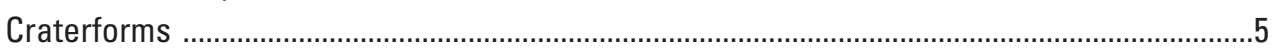

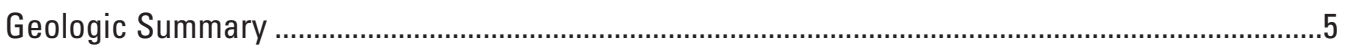

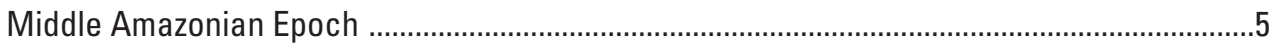

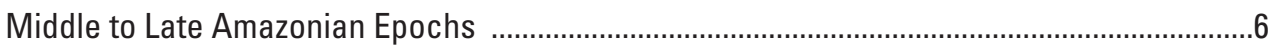

Late Amazonian Epoch ..........................................................................................................

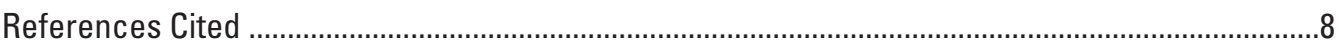

\section{Table}

1. Relative age determinations for geologic units in the Olympia Rupēs region of Mars.

\section{Figures}

1. Color shaded-relief image of MTM 85200 constructed from a digital elevation model of Mars Orbiter Laser Altimeter data (512 pixels/degree; $115 \mathrm{~m} /$ pixel) (map sheet)

2. Excerpt of CTX image number P01_001341_2654 (centered at lat $85.21^{\circ} \mathrm{N}$., long $147.19^{\circ} \mathrm{E}$.; location shown on map) that shows local geomorphology that occurs within the Planum Boreum 1 unit $\left(A b_{1}\right)$

3. Excerpt of High Resolution Imaging Science Experiment image number PSP 001548-2755 (centered at lat $84.39^{\circ} \mathrm{N}$., long $142.94^{\circ}$ E.; location shown on map) that shows a scarpexposed section of layered deposits south of the Olympia Rupēs

4. Excerpt of Mars Orbiter Camera narrow-angle image number e03-02719 (centered at lat $85.14^{\circ} \mathrm{N}$. , long $168.76^{\circ} \mathrm{E}$.; location shown on map) that shows unit relations near the eastern termination of a polar trough, south of the Olympia Rupēs

5. Excerpt of Context Imager (CTX) image number P02_001670_2643 (centered at lat $84.94^{\circ} \mathrm{N}$., long $176.56^{\circ}$ E.; location shown on map) that shows the margin of a scarp-exposed section of the Olympia Cavi 1 and Planum Boreum 1 units $\left(A_{0 c} c_{1}\right.$ and $\left.A b_{1}\right)$ along Olympia Rupēs 
This page intentionally left blank 


\section{Introduction}

The Martian polar plateaus are likely to contain a record of global climate history for $<10^{7}$ to as much as $\sim 3 \times 10^{9}$ years (Tanaka and others, 2008; Byrne, 2009; Banks and others, 2010). This record is partly observable as rhythmically layered deposits exposed in the curvilinear troughs of the north polar plateau, Planum Boreum (Cutts and others, 1976, 1979; Cutts and Lewis, 1982; Howard and others, 1982). The north polar layered deposits are widely interpreted to be among the most youthful bedrock deposits on the Martian surface (Byrne, 2009). These materials and their stratigraphic and structural relations provide a glimpse into some of the more recent geologic processes that have occurred on Mars. The ability of the massive polar deposits to periodically trap and release both volatiles and lithic particles may represent a globally important, recurring geologic process for Mars (for example, Byrne, 2009).

The north polar and circum-polar deposits were first mapped using Mariner 9 images at 1:25,000,000 scale by Scott and Carr (1978), who identified variously textured plains surrounding the polar deposits. A subsequent regional-scale (1:5,000,000 scale) geologic and geomorphologic map was produced using Viking Orbiter images by Dial (1984), who outlined boundaries of various types of polar dune deposits. This effort was followed by a Viking-based map (1:15,000,000 scale) that employed significant stratigraphic revisions (Tanaka and Scott, 1987). These workers delineated two Late Amazonian polar plateau units (unit Apl, polar layered deposits, and unit Api, polar ice deposits), which were interpreted to be diachronous, implying spatially variable deposition through time. Tanaka and Scott (1987) also mapped three discrete, Late Amazonian, circum-polar units (in addition to textural members of the circum-polar Vastitas Borealis Formation), including crescentic dune material (unit Adc), linear dune material (unit Adl), and mantle material (unit Am). Local, quadrangle-scale (1:500,000) mapping of Planum Boreum was completed by Dial and Dohm (1994) and Herkenhoff (2003) using Viking Orbiter images. These maps helped to improve the understanding of the internal characteristics of local outcrops of the polar layered deposits, including location and continuity of angular unconformities, surficial textures, and the occurrence of impact craters.

Post-Viking Orbiter datasets significantly improve geologic map-based characterizations of the polar deposits and require refined mapping methodologies (for example, Tanaka and others, 2008). The most recent geologic map of the Martian north polar deposits is hemispheric in scale $(1: 15,000,000)$ and used data sets from the Mars Global Surveyor (MGS) and Mars Odyssey (MO) orbiters (Tanaka and others, 2005). This map used the Mars Orbiter Laser Altimeter (MOLA) gridded topographic data sets at $\sim 465 \mathrm{~m} / \mathrm{pixel}$ as its primary base map. Contacts and unit descriptions therein were refined using local coverage of MGS Mars Orbiter Camera (MOC) and MO Thermal Emission Imaging System (THEMIS) images. Tanaka and others (2005) discriminated two discrete units of the north polar layered deposits, each identified by thickness, number of observable laminae, and vertical location as observed in equator-facing slopes of the polar troughs. Tanaka and others (2005) instituted mapping methods that differed from previous approaches as a means to effectively balance the availability and widespread coverage of high-resolution panchromatic images, topographic detail, and spectral information. More recently, Tanaka and Fortezzo (2012) completed a 1:2,000,000scale regional geologic map of Planum Boreum and its immediately surrounding environments. In addition to four units mostly confined to the circumpolar plains, these workers identified a sequence of five units that collectively defines the volumetric and areal bulk of the north polar plateau. Their sequence is bracketed by the Late Hesperian rupēs unit (unit $\mathrm{HBb}_{\mathrm{r}}$ ), based on its dominant occurrence along the scarp-forming margins of Planum Boreum, and the Late Amazonian Planum Boreum 3 unit. As mapped by Tanaka and Fortezzo (2012), the geologic materials exposed in the north polar plateau reflect a long-lived, cyclic, and regional-scale history of accumulation, erosion, and redistribution of sand, dust, and ice deposits. Though the broad-scale absence of impact craters hinders the stratigraphic correlation of most polar materials to extant circumpolar and mid-latitude deposits, a certain level of inference can be made based on material depth, appearance, and lateral relations, as well as the estimated record of polar insolation through time (Laskar and others, 2002, 2004).

Summertime albedo features on the north polar plateau, such as dark bands, correspond well with the location of curvilinear troughs (Cutts, 1973). This effect is most pronounced on the steeper, equator-facing trough walls, where the margin of the residual (perennial) ice cap shifts over time. Changes in the extent of the residual ice cap have been noted across the north polar plateau (Malin and Edgett, 2001; Hale and others, 2005) but are limited in area and appear to be reversible over a few Martian years (Byrne and others, 2008). During wintertime, the bulk of the polar plateau is covered in a $\sim 1-\mathrm{m}$-thick layer of seasonal $\mathrm{CO}_{2}$ frost (Titus and others, 2008), which generally obscures fine-scale surface morphology and albedo contrasts.

Data provided by topographic and satellite-based surface imaging instrument systems, particularly the Mars Reconnaissance Orbiter (MRO) High Resolution Imaging Science Experiment (HiRISE) and Context (CTX) cameras, are increasingly showing that the materials of the Mars north polar plateau reflect a complex history of material accumulation and degradation (Tanaka and others, 2008; Tanaka and Fortezzo, 2012). Analysis of post-Viking Orbiter high-resolution image data has confirmed and, in many instances, improved upon standing hypotheses concerning Martian polar geology. Such refinements focus on (1) temporal sequencing of layered deposit accumulation and degradation (Phillips and others, 2008; Tanaka and others, 2008; Banks and others, 2010), (2) geomorphic and stratigraphic partitioning of basal sequences from overlying "layered deposits" (Byrne and Murray, 2002), (3) origination and evolution of polar troughs and swales (Howard, 2000; Ng and Zuber, 2006; Smith and Holt, 2010), (4) linking of polar strata with obliquity cycles over the past few million years (Laskar and others, 2002, 2004; Milkovich and Head, 2005; Fishbaugh and others, 2010), (5) correlation of circumpolar materials to layer packages and unconformities (Tanaka and others, 2003, 2005, 2008), and (6) detailing of the internal composition of polar materials (Picardi and others, 2005; Murchie and others, 2007; Phillips and others, 2008). 
The extensive spatial coverage, high resolution, and diversity of modern (post-Viking Orbiter) data sets of Mars have ushered in a new era of geological map creation, presentation, and utility. The map described herein is of particular scientific relevance because it is the largest-scale geologic map produced for the polar deposits of Mars using post-Viking Orbiter data sets. As a result, it provides a point of comparison for smallerscale geologic maps, particularly the recent 1:2,000,000-scale regional map of Planum Boreum by Tanaka and Fortezzo (2012). The geologic, morphologic, and stratigraphic details conveyed in this 1:500,000 map of Mars Transverse Mercator (MTM) 85200 quadrangle offer an improved means to visualize, represent, and interpret the local geologic history of Martian polar deposits, as observed in the Olympia Rupēs region of Planum Boreum.

\section{Physiographic Setting}

The north polar region of Mars is dominated by Planum Boreum, a roughly circular, domical plateau that rises $>2,500$ $\mathrm{m}$ above the surrounding lowland (Smith and others, 2001). Planum Boreum is $>1,500 \mathrm{~km}$ in diameter, contains deep, curvilinear troughs and chasmata, isolated cavi, and marginal scarps and slopes. The north polar plateau is surrounded by low-lying and nearly horizontal plains of various surface texture, geologic origin, and stratigraphic significance (Tanaka and others, 2005, 2008; Tanaka and Fortezzo, 2012).

The MTM 85200 quadrangle spans $5^{\circ}$ of latitude (lat $82.5^{\circ}$ to $87.5^{\circ} \mathrm{N}$.) and $40^{\circ}$ of longitude (long $140^{\circ}$ to $180^{\circ} \mathrm{E}$.) within the eastern hemisphere of Mars (fig. 1). The quadrangle includes the high-standing Planum Boreum, curvilinear troughs of Boreales Scopuli, deep, sinuous scarps of Olympia Rupēs, isolated and coalesced depressions of Olympia Cavi, margins of the circular polar erg Olympia Undae, and lowstanding Olympia Planum. The surface of Planum Boreum within the MTM 85200 quadrangle is characterized by smoothly sculptured landforms with shallow slopes and variable relief at kilometer scales (Zuber and others, 1998; Tanaka and others, 2008). Areas that are perennially covered with bright frost are generally smooth and planar at 100-m scales (Cutts and others, 1979). However, MGS MOC and MRO HiRISE images show that much of the icy polar plateau is rough at decameter scale (Thomas and others, 2000; Herkenhoff and others, 2002).

We subdivide the north polar plateau in the MTM 85200 quadrangle into the Boreum and Olympia regions to assist with identifying and describing units and succinctly conveying the interpreted geologic history (table 1). These regions are separated by an east-west-trending system of arcuate scarps (Olympia Rupēs) that elevate Planum Boreum by $\sim 800 \mathrm{~m}$ above Olympia Planum (fig. 1). The Boreum region contains the highstanding, inter-trough polar flats that have high-albedo surfaces during the polar summer (solar longitude $\left(\mathrm{L}_{\mathrm{s}}\right)$ from $90^{\circ}$ to $180^{\circ}$ ). Polar troughs extend from approximately $-2,700 \mathrm{~m}$ elevation near the center of the polar cap to approximately $-4,300$ $\mathrm{m}$ elevation along the north margins of Olympia Planum. The
Olympia region contains the low-standing cavi margins and floors that have intermediate to low albedo, as well as the northern parts of Olympia Undae.

\section{Map Base And Data}

Though photogeology and geomorphology continue to define the cornerstone of planetary geologic mapping (Greeley and Batson, 1990), new techniques are required to most effectively convey stratigraphic and structural relations using voluminous data sets of diverse type and spatial resolution. We describe below (1) the construction and use of the geologic map base and (2) the relevance and use of supplemental mapping datasets.

The primary base for this geologic map was originally a Viking Orbiter mosaic of individual images acquired during the 1976 Martian northern summer $\left(\mathrm{L}_{\mathrm{S}}\right.$ from $133^{\circ}$ to $\left.135^{\circ}\right)$. The original intent of the Viking Orbiter base photomosaic was to provide a time-controlled view of the extent of polar ice during its presumed minimal extent, similar to the MTM 85080 quadrangle mapped by Herkenhoff (2003) (see quadrangle location map on map sheet for location). These types of data sets were previously used to identify both volatile and nonvolatile units in both the northern and southern polar plateaus (for example, Herkenhoff and Murray, 1990; Herkenhoff, 2003). However, as noted by Herkenhoff (2003), the resolution of Viking Orbiter color mosaics is not generally sufficient to clearly and consistently identify geologic units based on morphologic detail and crosscutting relations (table 1). As a result, for the MTM 85200 geologic map, we used the time-controlled Viking Orbiter mosaic in tandem with the MOLA digital elevation model (DEM) at 512 pixels/degree ( $115 \mathrm{~m} /$ pixel). This "blended" base map provides not only summertime albedo but also topographic characteristics that are important to the identification of geologic units at 1:500,000 scale. The units that are mapped and described herein are tied to this blended base map due to its full areal coverage of the selected quadrangle. High-resolution data sets (described in subsequent sections) were used as supplements for the evaluation of contact location, identification and description of geologic units, and assessment of stratigraphic relations (table 1).

The Viking Orbiter image mosaic that was originally provided by the U.S. Geological Survey (USGS) was created using outdated geodetic information, resulting in an offset between modern data sets and the map base (Seidelmann and others, 2002). To correct this cartographic shift, we applied a secondorder polynomial transformation to fit the USGS-produced Viking Orbiter mosaic to the MOLA DEM using georeferencing tools available in geographic information system (GIS) software packages. The transformation utilized 36 hand-picked points between easily identifiable landforms within the unregistered Viking Orbiter mosaic and the controlled MOLA DEM. This spatial transformation resulted in a root mean square (rms) error in horizontal placement of $354 \mathrm{~m}$, which translates to $0.7 \mathrm{~mm}$ at map scale. We overlaid the rectified Viking Orbiter mosaic on the MOLA-derived shaded-relief image to produce the blended 
base map rendered in the geologic map. This approach allowed us to tie the Viking Orbiter seasonal information to the more accurately controlled MOLA DEM and other modern datasets. The inclusion of MOLA topography in the base allows for diminished use of topographic symbology on the map (unless used where imperative to convey the geologic history) and a more concise representation of the geologic environment. However, topographic information is significantly reduced north of lat $87.1^{\circ} \mathrm{N}$. due to the polar orbit of the MGS satellite and resultant spacing between MOLA ground tracks. Therein, geologic contacts were identified exclusively by examination of the Viking Orbiter mosaic. The resultant base-map scale is 51 $\mathrm{m} /$ pixel, which translates into approximately 10 pixels $/ \mathrm{mm}$ at map scale.

Though the map base provided the contextual information necessary to consistently map contacts and temporally correlate geologic units (table 1), we verified and honed these efforts by integrating other data sets, including MOLA-derived products (cell-to-cell slope, aspect, and color-shaded-relief maps) and the full range of THEMIS, MOC, HiRISE, and CTX images via web-linked image footprints in the project GIS. Though these data sets provided important information regarding unit texture and stratigraphic relations, they were considered supplemental because they did not provide complete areal coverage at the map scale. Supplemental data sets were used to complete the accompanying Description of Map Units where clear and consistent textural and (or) stratigraphic characteristics were observed.

\section{Methodology}

This geologic map was compiled using methods that both follow and deviate from the approaches used by Tanaka and others (2005) in their hemisphere-scale geologic map of the northern plains of Mars. We describe below the (1) rationale for unit groups, names, and symbols, (2) types and relevance of geologic contacts, (3) types and relevance of feature symbols, and (4) digital drafting parameters used to compile information.

\section{Unit Groups, Names, and Symbols}

We name the discrete geologic materials that occur within MTM 85200 using nonmorphologic and nongenetic terms to preserve objectivity by avoiding potentially erroneous genetic connotations. Tanaka and others (2005) subdivided the Martian northern plains into specific physiographic provinces and uniquely denoted the geologic units that occurred within these provinces as a means to partition the regional geologic histories and simplify description. The MTM 85200 quadrangle falls entirely within the Borealis province of the northern plains, as defined by Tanaka and others (2005). For clarity, we group the units of MTM 85200 into two regions based on IAU-approved nomenclature. The Boreum region units of MTM 85200 are those that comprise the polar flats and troughs of Planum Boreum, which are generally identified north of the Olympia Rupēs (fig. 1). The Olympia region units of MTM 85200 are those that occur within and directly adjacent to the Olympia region of Mars (centered at lat $80^{\circ} \mathrm{N}$., long $160^{\circ} \mathrm{E}$.) are generally identified south of the Olympia Rupēs. These groupings are shown on the Correlation of Map Units.

We name the units of MTM 85200 based on their geographic occurrence and relative stratigraphic position (table 1). We identify seven geologic units within the quadrangle: three units of the Boreum region and four units of the Olympia region. The Boreum units consist, from oldest to youngest, of the Planum Boreum 1, Planum Boreum 2, and Planum Boreum 3 units. The Olympia units consist, from oldest to youngest, of the Olympia Cavi 1, Olympia Cavi 2, and Olympia Cavi 3 units, as well as the Olympia Undae unit.

Units are assigned a unit label that uniquely identifies (1) the chronologic period (for example, $A=$ Amazonian period), (2) the geographic region (for example, $\mathrm{O}=$ the Olympia region), (3) the physiographic feature name where more than one geologic unit occurs in a region (for example, $\mathrm{c}=$ Olympia Cavi), and (4) the interpreted stratigraphic sequence (for example, $1=$ the first/oldest of two or more related geologic units). For example, the unit label, Aoc 1 , refers to the Amazonian-age, stratigraphically lowest unit that occurs within and (or) adjacent to Olympia Cavi. We specifically note that the unit labels used herein differ from those applied in regional- to hemisphere-scale maps, because we do not indicate physiographic province (for example, $\mathrm{B}=$ Borealis province of Tanaka and others (2005) and Tanaka and Fortezzo (2012)). We justify this deviation because quadrangle-based geologic maps generally include discrete materials that occur within a single physiographic province. We denote the physiographic province within the headings in the Correlation of Map Units and Description of Map Units rather than include it in the geologic unit label. As a result, quadrangle schemes can utilize more simplified labels that are specific to large-scale geologic maps.

We acknowledge and underscore that different approaches to labeling and naming map units can introduce confusion where competing maps apply discrepant symbols for similar geologic units (or similar symbols for discrepant units). We specifically point out that some unit labels applied herein partly contrast and conflict with those units employed by Tanaka and Fortezzo (2012) in their 1:2,000,000-scale geologic map of Planum Boreum. However, we feel that the absence of physiographic province in our unit labels (as described above) adequately partitions potentially confusing unit labels. For clarity, we note association or overlap of our units with those of other published maps in the Geologic Summary section of this text.

\section{Contact Types}

We define and delineate geologic units using contacts that denote their interpreted level of certainty and (or) their geologic occurrence. A certain contact denotes the most precise contact between well-characterized geologic units that contrast in appearance and (or) interpreted relative age. An approximate geologic contact is regarded as less precise in its spatial placement due to data quality, subtlety of contact, and (or) obscura- 
tion by secondary processes, where the existence of a geologic unit is generally not in question.

\section{Feature Types}

The map includes a variety of morphologic feature symbols, following precedents established in previous terrestrial and planetary geologic maps. Although consistent mapping of features is desired, it is generally not possible or practical due to complications that can arise from (1) locally rugged terrain; (2) variation in feature character, length, and (or) relief; (3) feature orientation relative to illumination; and (4) areas of low data resolution and (or) data coverage. The features that are mapped in the MTM 85200 quadrangle grade in appearance and overlap in places and should be considered cartographic rather than exact representations, in regard to spatial placement and density. We mapped ridges, berms, unconformities, swales, scarps, knobs, depressions, sediment transport directions, and craterforms.

\section{Digital Drafting Parameters}

We used the Environmental Systems Research Institute, Inc. (v. 9.3, 1982-2011, Redlands, CA) ArcGIS software package to co-register and analyze available datasets. We digitized points, lines, and polygons using the digital streaming capability in ArcGIS. We digitized vector linework at a consistent scale of $1: 125,000$ (25\% of the publication map scale), which allowed for substantially detailed lines for use in a hard-copy map publication, as well as a digital product, while remaining true to the publication map scale of 1:500,000. Vertex spacing was controlled in ArcGIS and was set to place spatial points within linework every $125 \mathrm{~m}$ (1 vertex per $1 \mathrm{~mm}$ at 1:125,000 digitizing map scale).

Linework was streamed using a WACOM Intuos 3 digital mapping tablet into an ArcGIS digital geodatabase in polar stereographic projection. The geodatabase housed the attribute information for each digitized feature. Attributes for linework were assigned iteratively using attribute domain settings stored within the geodatabase. Geologic map symbols were derived from Federal Geographic Data Committee Digital Cartographic Standards for Geologic Map Symbolization (FGDC, 2006) and were adapted where necessary to convey the geologic information unique to the quadrangle. Subsequent editorial iterations of the digitized linework allowed for refinement of contact placement and unit descriptions based on cross-comparison between the map base and supplemental data sets. Contact linework was cleaned (dangles removed) and used to build unit polygons. To balance base map resolution and clear cartographic representation, all unit outcrops are $>1 \mathrm{~km}^{2}$.

\section{Geomorphology}

The spatial and morphologic characteristics of landforms that occur within the geologic units of the MTM 85200 quad- rangle provide information helpful to the discernment of the regional geologic history.

\section{Ridges}

Ridges are the peaks of relatively sharp crested lineaments that occur on the inter-trough polar plateau, generally south of Olympia Rupēs. Ridges are most commonly oriented oblique to the axes of nearby polar troughs. These features generally parallel low-albedo surface streaks ("veneers" of Rodriguez and others, 2007), as well as the sediment transport direction as determined from duneform shape. We mapped 58 ridges within the quadrangle ranging in length from 1.4 to $5.6 \mathrm{~km}(2.6 \mathrm{~km}$ mean), though high-resolution images show a greater density than we identify using the basemap. Ridges occur entirely within the boundary of the Planum Boreum 3 unit.

\section{Berms}

Berms are the crestlines of curvilinear, convex-upward ridges that occur on equator-facing trough walls north of Olympia Rupēs (fig. 2). Berms are several hundreds of meters wide and occur adjacent to (and can linearly grade into and from) scarps and unconformities. The features sometimes form the margins of lens-shaped benches within polar troughs (for example, lat $86.08^{\circ} \mathrm{N}$., long $164.47^{\circ} \mathrm{E}$.). We mapped 21 berms within the quadrangle ranging in length from 3.7 to 30.4 $\mathrm{km}$ (11.3 km mean). Berms occur entirely within the Planum Boreum 1 unit and may represent layers of contrasting friability within the polar stratigraphic sequence (see Geologic Summary section for elaboration).

\section{Swales}

Swales are the axes of shallow, asymmetric, curvilinear depressions that occur on the inter-trough flats of Planum Boreum both north and south of Olympia Rupēs. These features were initially recognized and mapped by Cutts and others (1979) and Howard and others (1982) and assist in defining the shallowly undulating, wavelike topography between troughs of the north polar plateau. We use the term "swale" to denote the axial trend of depressions that occur within otherwise horizontal intertrough flats as opposed to the term "undulations" of Howard and others (1982), which emphasizes the collective wavelike characteristics of inter-trough regions based on lower resolution Viking Orbiter-based topography. As mapped herein, swales generally range from $\sim 1$ to $>5 \mathrm{~km}$ wide, are as much as $100 \mathrm{~m}$ deep, and are bounded on both sides by low-angle slopes. Bounding slopes are generally less than $5^{\circ}$ and we subdivide these based on bounding slopes greater than and less than $2^{\circ}$. Slopes as high as $8^{\circ}$ occur locally where swales curve into trough terminations. We mapped 89 swales within the quadrangle ranging in length from 3.1 to $60.2 \mathrm{~km}$ (11.3 mean). Swales with bounding slopes $<1^{\circ}$ were not mapped. Swales occur predominantly within Planum Boreum 2 unit, though genetic association with the Planum Boreum 1 and 3 units cannot be ruled out. 


\section{Scarps}

Scarps are the sharp or subdued breaks in slope that form the margins of topographic ledges within equator-facing walls of polar troughs (for example, lat $86.74^{\circ} \mathrm{N}$., long $173.78^{\circ} \mathrm{E}$.), depressions within Olympia Cavi (for example, lat $85.26^{\circ} \mathrm{N}$., long $160.05^{\circ} \mathrm{E}$.), and topographically shallow inflections on the polar plateau south of Olympia Rupēs (for example, lat $84.00^{\circ}$ N., long $174.30^{\circ} \mathrm{E}$ ). Scarps can be partly or fully enclosed to form knobs or depressions and locally appear to grade laterally into berms. Scarps form within the Olympia Cavi 1, Planum Boreum 2, and Planum Boreum 3 units and appear to be buried by the Planum Boreum 3 and Olympia Cavi 3 units.

\section{Unconformities}

Unconformities are curvilinear features that demarcate the truncation of stratigraphic layers exposed in the equatorfacing walls of polar troughs. Some sections of truncated strata are linked by layers with discrepant morphologic or albedo characteristics (for example, lat $85.18^{\circ} \mathrm{N}$., long $146.85^{\circ} \mathrm{E}$.). Unconformities are interpreted to represent periods of erosion. We mapped 12 unconformities within the quadrangle ranging in length from 1.3 to $23.1 \mathrm{~km}$ (5.8 km mean). Unconformities are mapped only within the Planum Boreum 1 unit, although the variable topographic character of the upper stratigraphic boundaries of the Olympia Cavi 1, Planum Boreum 1, Olympia Cavi 2, and Planum Boreum 2 units are interpreted as unconformities (see Descriptions of Map Units for elaboration).

\section{Sediment Transport Direction}

Sediment transport direction was inferred from duneform shape as evidenced in both regional base maps and high-resolution images. Barchan and crescent duneforms are the dominant landform within the Olympia Undae unit, which occurs on the floors of Olympia Cavi as well as along the northern margin of Olympia Planum. Sediment transport direction is meant to convey the overall sense of transport and wind direction, though it is generally not known whether saltation is a current geologic process affecting the materials of the north polar plateau. Sediment transport directions show general transport in the southwesterly direction, though local topography within Olympia Cavi appears to have caused localized deviations in these directions (Tanaka and others, 2008).

\section{Craterforms}

We mapped two craterforms within the quadrangle (informally named "crater A" and "crater B"). Each is defined by circular depressions with very subdued rims and no associated surrounding deposits. Crater A is an approximately 150-m-diameter bowl-shaped feature that resides within the Olympia Cavi 1 unit at lat $84.37^{\circ} \mathrm{N}$., long $142.80^{\circ} \mathrm{E}$ (fig. 3). Based on measurement in MOLA gridded data, the feature forms the top of a 160$\mathrm{m}$-tall topographic promontory within a cavus. The craterform feature may be an eroded vestige of an impact crater within the Olympia Cavi 1 unit. As such, the bowl-shaped features may only represent a part of the interior wall and floor of the original impact structure of a larger diameter than measured. Crater B is an approximately 200-m-diameter bowl-shaped feature that resides within the Planum Boreum 1 unit at lat $85.15^{\circ} \mathrm{N}$., long $168.88^{\circ} \mathrm{E}$. (fig. 4). The craterform is partly filled or abutted by Planum Boreum 2 unit near a trough termination. In addition to the two craterforms that we mapped herein, Banks and others (2010) identified four other similarly shaped features within the quadrangle boundary, based on analysis of CTX and HiRISE images; these range from 39 to $52 \mathrm{~m}$ in diameter and occur primarily in the Planum Boreum 2 and 3 units.

\section{Geologic Summary}

The stratigraphic architecture of the north polar plateau of Mars is refined through quadrangle-scale geologic mapping, wherein local unit characteristics and geologic relations can be conveyed cartographically (table 1). The evolution of the materials that make up the north polar plateau (including those within the MTM 85200 quadrangle) is not temporally well constrained due to a paucity of impact craters on the north polar plateau (Herkenhoff and Plaut, 2000; Herkenhoff, 2003; Tanaka and others, 2008; Banks and others, 2010; Tanaka and Fortezzo, 2012), the densities of which are helpful in providing some stratigraphic control. Recent regional-scale mapping (Tanaka and others, 2005; Tanaka and Fortezzo, 2012) and topical science investigations (Tanaka, 2005; Tanaka and others, 2008; Banks and others, 2010) help provide some stratigraphic control for the materials of Planum Boreum, including geologic and (or) stratigraphic equivalents to those mapped herein. We employ these controls where possible. However, we note that some temporal context gleaned from other investigations is based on observations made outside of the MTM 85200 map area, including crosscutting relations and small population crater densities (with inherent large uncertainties). The geologic summary discussed herein is portrayed graphically in the Correlation of Map Units. Details of the stratigraphic relations are provided in the Description of Map Units.

\section{Middle Amazonian Epoch}

The oldest unit that we identify is the Olympia Cavi 1 unit $\left(\right.$ Aoc $\left._{1}\right)$, which is distinguished from adjacent units by its variable (though generally low) albedo and rugged, tabular appearance (figs. 3, 5). Unit Aoc 1 forms most of the lower elevation walls and floors of Olympia Cavi. Crossbeds are locally apparent on clean (unmantled) surfaces. The unit's lowermost sections (outcropping in the deepest cavi) are commonly made up of evenly layered light and dark material (fig. 5), which often reveals intricate, light-dark swirled patterns when eroded. Because it is the lowest exposed unit within the quadrangle, the stratigraphic nature of the Olympia Cavi 1 unit's lowermost contact is temporally unconstrained. Based on the identification of an equivalent unit by Tanaka and others (2008), we infer a 
commencement of deposition near the beginning of the Middle Amazonian and a cessation at an unspecified time during the Middle Amazonian. However, a paucity of impact craters on this unit both within and outside of the MTM 85200 quadrangle means this emplacement range should be viewed as approximate (Tanaka and others, 2008).

Unit $A_{0} c_{1}$ is generally equivalent to the more regionally occurring Planum Boreum cavi unit of Tanaka and Fortezzo (2012). However, those workers do not map the equivalent unit as pervasively within the Olympia Cavi as we do herein, opting instead to map a younger, tens-of-meters-thick lag deposit that obscures the discriminating characteristics of subjacent material. The lag deposit is identified herein as the Olympia Cavi 2 unit (Aoc2), described below. Tanaka and Fortezzo (2012) also suggest that the younger lag deposit buries a Late Hesperian unit that broadly underpins the north polar plateau, termed the "Planum Boreum rupēs unit." We do not identify a unit that is equivalent to the rupēs unit of Tanaka and Fortezzo (2012) within the boundaries of the MTM 85200 quadrangle; we instead interpret the Olympia Cavi 1 unit as the stratigraphically lowest exposed unit (see cross sections, map sheet). Regional observations, however, suggest the possibility that the Planum Boreum rupēs unit of Tanaka and Fortezzo (2012) exists beneath the materials mapped herein, but that it is either not exposed within the Olympia Cavi or it is thinly buried by younger units. For context and comparison, we have shown the stratigraphic position of unit AHBr from Tanaka and Fortezzo (2012) in the Correlation of Map Units. The Olympia Cavi 1 unit is also partly equivalent to the platy unit of Byrne and Murray (2002), the mantle unit of Herkenhoff (2003), and the basal unit of Fishbaugh and Head (2005).

We interpret the Olympia Cavi 1 unit to have been deposited as layers of dark lithic sand and dust, layered with (and perhaps bound by) ice during varied atmospheric conditions driven by orbital/axial oscillations. Occasional evidence of crossbedding indicates that the unit is partly aeolian in origin, though sparsely occurring light and dark near-horizontal layers perhaps point toward intermittent deposition through atmospheric fallout. The unit may have partly accumulated in similar fashion to the layered deposits of the Planum Boreum 1 and 2 units (described below), with a supply of dark sand being exhausted before the Planum Boreum 1 unit was emplaced (Herkenhoff and others, 2007). Based on the rugged, slabby appearance and thin scale of internal stratification, we suggest that unit Aoc $_{1}$ underwent intensive, syndepositional or postdepositional devolatilization, compaction, and eventual erosion and surface deflation; primary depositional characteristics do not always appear to be well preserved.

Variable elevation of the uppermost surface of the Olympia Cavi 1 unit suggests that the unit's vertical accumulation was followed by erosion, deflation, and localized downcutting (see cross sections), perhaps driven by off-pole katabatic winds (Howard, 2000; Kolb and Tanaka, 2001; Byrne and Murray, 2002; Tanaka and others, 2008). This activity may have formed an uneven, undulating paleosurface onto which younger deposits were emplaced. Localized erosion may also have resulted in the formation of prototroughs - topography that persisted during the accumulation of subsequent geologic sequences.
Following an indeterminate period of time, the Planum Boreum 1 unit $\left(A b_{1}\right)$ began accumulating on the unit $A_{0} c_{1}$ paleosurface. Unit $A b_{1}$ is made up almost entirely of a largely undifferentiable sequence of rhythmic layers (figs. 3, 5), with unconformities (documented by truncated layers) occurring intermittently within the stratigraphic sequence (fig. 4). Because such unconformities are not concentrated near the bottom of the exposed unit $A b_{1}$ sequence, we suggest that the lower contact of this unit is stratigraphically certain, implying commencement of deposition within a narrow window of geologic time. This contrasts with the regional observations and interpretations of Tanaka and Fortezzo (2012), who perceive the transition between their regionally equivalent units to be time-transgressive. These contrasting interpretations indicate that timetransgression between units $A o c_{1}$ and $A b_{1}$ suggested by Tanaka and Fortezzo (2012) was spatially confined to particular regions of Planum Boreum and did not occur inside of the MTM 85200 quadrangle boundary. The Planum Boreum 1 unit is generally equivalent to polar layered deposits of Tanaka and Scott (1987), the layered deposits of Herkenhoff (2003), the lower layered deposits of Tanaka (2005), and the Planum Boreum 1 unit of Tanaka and others (2008) and Tanaka and Fortezzo (2012).

The rhythmic and laterally continuous layers within the Planum Boreum 1 unit implicate accumulation of ice and dust through atmospheric fallout, perhaps as the result of orbit-controlled climate oscillations (Laskar and others, 2002, 2004) and (or) far-field volcanism and surface impact. Consistent traceability and thick outcrops suggest that unit $A b_{1}$ constitutes the volumetric bulk of the north polar plateau (see cross sections). However, unit accumulation appears to have been spatially inconsistent, as evidenced by unconformities within the unit. Localized erosion may have resulted, in part, from the focusing of katabatic winds in surface swales, which preferentially accumulated dust when deposition resumed. The occurrence of curvilinear ridges (mapped as berms; fig. 2) and scarps within unit $A b_{1}$ and their lateral traceability to unconformities suggests that erosion may have been partly influenced by strength differences between adjacent layers, perhaps due to variation in grain size, dust content, or degree of material induration/ice annealing. Such variations may have formed when the ice-rich material was exposed to insolation or during a resumption of deposition following localized depositional hiatus or erosion.

\section{Middle to Late Amazonian Epochs}

The widespread deposition of the Planum Boreum 1 unit within the MTM 85200 quadrangle was followed by widespread erosion, surface deflation, and localized downcutting, which resulted in the formation of an upper unconformity upon which younger units were deposited (see cross sections). Tanaka (2005) suggested that the eroded surface of this unit is $\sim 5$ m.y. old, based on crater retention ages, perhaps corresponding to a major decrease in Mars' obliquity and a resultant decrease in insolation on the north polar plateau (Laskar and others, 2002). However, the paucity of craters on this unit, as well as the interpretation that the unit underwent large-scale erosion (presumably destroying any accumulated craters), indicates that 
crater-based temporal constraints provide only an indication of when erosion significantly waned (Tanaka and Fortezzo, 2012). Thus, the time period over which unit $A b_{1}$ not only accumulated but also eroded is poorly constrained, as noted by Tanaka and others (2008).

The Olympia Cavi $2\left(\mathrm{Aoc}_{2}\right)$ unit was deposited on the eroded vestiges of units $A o c_{1}$ and $A b_{1}$, where it formed a draping unit of variable thickness. We note, however, that the lower contact of unit $\mathrm{Aoc}_{2}$ is not well constrained, perhaps indicating that accumulation of that unit was partly coeval with the erosion of unit $A b_{1}$. Unit $A o c_{2}$ is characterized by its low to intermediate albedo and its occurrence at the base of trough scarps and on cavi slopes and floors, mostly south of Olympia Rupēs (figs. 3, 5). We interpret the Olympia Cavi 2 unit as discontinuous layers of sediment and ice, perhaps eroded from the underlying Olympia Cavi 1 and the Planum Boreum 1 units. Erosion of unit $A_{1}$ may have resulted from sublimation of layered and interstitial ices, which allowed for the mobilization, transport, and redeposition of lithic materials as unit Aoc 2 . Lithic inputs from outside of the map region, perhaps sourced from deep cavi immediately to the east of the map area (Tanaka and others, 2008), may also have added significant components to unit $\mathrm{Aoc}_{2}$.

Unit $A_{0} c_{2}$ drapes older units, suggesting that it preferentially accumulated in topographic lows of the polar flats and cavi. However, the paleosurface of this unit, as it occurs beneath mapped materials, is difficult to determine. Traceability of unit Aoc $_{2}$ outcrops shows its characteristic occurrence between units $A b_{1}$ and $A b_{2}$ (fig. 5) and thickening in topographic catchments, perhaps implying an aeolian origin (also suggested by Tanaka and Fortezzo, 2012). It is important to recognize that the Olympia Cavi 2 unit mapped herein is roughly equivalent to the "intermediate unit" of Rodriguez and others (2007) and the "Planum Boreum 2 unit" of Tanaka and Fortezzo (2012). Each of these units is interpreted to be a Middle to Late Amazonian dust and sand lag deposit derived from the erosion of subjacent units. In contrast to regional mapping results of Tanaka and Fortezzo (2012), however, we explicitly discriminate and partition those units of the MTM 85200 quadrangle that we interpret to have accumulated primarily through the widespread, rhythmic deposition of dust and ice (Boreum region units) and those that we interpret were deposited as eroded and redeposited lithic components from subjacent units (Olympia region units). In this geologic scenario, the erosion of Boreum region units is succeeded by the deposition of Olympia region units (and vice versa).

The Olympia Undae unit (Aou) comprises low-albedo duneforms and overlies and locally grades with unit Aoc2 (fig. 5). We interpret unit Aou as accumulations of eroded and redistributed sand. Preserved duneforms within the unit indicate that bulk transport directions were off the pole to the south and west. Due to proximity of outcrops, a source of unit Aou sand may be the Olympia Cavi 1 unit, which is interpreted to be less resistant to erosion than the overlying Planum Boreum 1 unit (Byrne and Murray, 2002; Tanaka and others, 2008). Alternatively (or perhaps in addition to), apparent gradation between unit Aou and unit Aoc $_{2}$ suggests that the latter may be a significant source for the dune sand. Though superposition relations with adjacent geologic units indicates that the Olympia Undae unit is one of the most recently active units within the quadrangle, its lowermost stratigraphic contact is uncertain. The Olympia Undae unit is partly equivalent to the crescentic dune material, linear dune material, and mantle material of Tanaka and Scott (1987) and the dune and mantle material of Tanaka (2005).

\section{Late Amazonian Epoch}

The Planum Boreum 2 unit $\left(\mathrm{Ab}_{2}\right)$ was emplaced above eroded vestiges of unit $A_{2} c_{2}$ as the result of seasonal to decadal climatic variations (Laskar and others, 2002, 2004), though the temporal nature of individual layers cannot be directly ascertained. The lithic fraction of unit $A b_{2}$, which is likely to be volumetrically minimal (Byrne, 2009), was perhaps derived from the erosion of subjacent units and (or) through atmospheric fallout. The lower contact grades into (and locally extends beneath) the Olympia Undae unit (see cross sections), particularly on pole-facing polar trough walls. Unit $\mathrm{Ab}_{2}$ mapped herein is correlative to the Planum Boreum 3 unit of Tanaka and Fortezzo (2012), who interpret the unit as Late Amazonian water ice with minor dust components and local thermokarst degradation. In addition, the Planum Boreum 3 unit is partly equivalent to the banded terrain of Howard and others (1982), partial frost cover of Herkenhoff (2003), and the upper layered deposits of Tanaka (2005). Unit $A b_{2}$ may represent the most recent episode of polar layered-deposit formation, because it unconformably overlies the bulk of Planum Boreum 1 unit outcrops and appears to fill small craters (Banks and others, 2010).

The Olympia Cavi 3 unit $\left(\mathrm{Aoc}_{3}\right)$ is thin (perhaps several meters thick) and has a low albedo and a smooth and diffusely lineated surface. Unit $\mathrm{Aoc}_{3}$, which is not differentiated as a separate unit in previous geologic maps, occurs south of the Olympia Rupēs on pole-facing, low-angle slopes and shallow swales on polar flats (cross section $\mathrm{B}-\mathrm{B}^{\prime}$ ). Unit $\mathrm{Aoc}_{3}$ forms irregularly shaped outcrops within unit $\mathrm{Ab}_{2}$ and appears to locally grade with units $A_{3}$ and Aou. Characteristic mixed albedo swirled patterns, which are mostly apparent in high-resolution images (for example, CTX P02_001670_2643), allude to weak, nearhorizontal internal stratification. We interpret the Olympia Cavi 3 unit to be composed of lithic particles, perhaps derived from the transport and redeposition of proximal outcrops of unit Aou, as well as topographically higher exposures of older units. The Olympia Cavi 3 unit represents localized sand sheets of equivalent composition to unit Aou but with a larger fraction of ice (based on albedo), perhaps occurring as poorly formed interbeds and (or) interstitial ice.

The Planum Boreum 3 unit $\left(A b_{3}\right)$ represents the extent of the north polar residual water ice cap (figs. 3, 4), as observed by Viking Orbiter 2 in 1976. It is interpreted to be a thin $(<1 \mathrm{~m}$ thick; Byrne and others, 2008) layer of water ice that unconformably overlies all other units within the map region; the lower contact represents the inferred onset of deposition. South of the Olympia Rupēs, clusters of narrow ridges occur within the boundaries of unit $A b_{3}$. These features may have formed within either unit $A b_{3}$ or the subjacent unit $A b_{2}$ through the action of cross-polar aeolian scour (ridges are oriented in the same direction as the inferred transport direction of regional 
dune fields). The Planum Boreum 3 unit is partly equivalent to the polar ice deposits of Tanaka and Scott (1986), the polar ice cap of Herkenhoff (2003), the Planum Boreum 2 unit of Tanaka and others (2003), the Planum Boreum 4 unit of Tanaka and others (2008), and the residual ice cap of Tanaka and Fortezzo (2012).

Hyperspectral observations indicate that the water ice in the residual cap is coarse grained, implying that the ice is old enough to have annealed (Byrne, 2009). Areas of lower albedo within the unit typically coincide with shallow topographic lows. In such instances, the lower albedo of subjacent unit $\mathrm{Ab}_{2}$ may be visible through the higher albedo, coarse-grained ice of unit $A b_{3}$. Alternatively, dust may be more concentrated in the low areas (Rodriguez and others, 2007). Spectral observations and high-resolution images of the unit's texture suggest that ice deposition has not occurred recently on the cap (Byrne, 2009). All units within the MTM 85200 quadrangle are covered annually by the north polar seasonal cap composed of carbon dioxide (Titus and others, 2008), which is not mapped herein.

\section{References Cited}

Banks, M., Byrne, S., Galla, K., McEwen, A., Bray, V., Fishbaugh, K., Dundas, C., Herkenhoff, K., Murray, B., and the HiRISE Team, 2010, Crater population and resurfacing of the Martian north polar layered deposits: Journal of Geophysical Research, v. 115, no. E08006 (doi:10.1029/2009JE003523).

Blasius, Karl, Cutts, James, and Howard, Alan, 1982, Topography and stratigraphy of Martian polar layered deposits: Icarus, v. 50, p. 140-160.

Byrne, S., 2009, The polar deposits of Mars: Annual Review of Earth and Planetary Sciences, v. 37, p. 535-560.

Byrne, S., and Murray, B.C., 2002, North polar stratigraphy and the paleo-erg of Mars: Journal of Geophysical Research, v. 107, no. E6 (doi:10.1029/2001JE001615).

Byrne, S., Zuber, M.T., and Neumann, G.A., 2008, Interannual and seasonal behavior of Martian residual ice-cap albedo: Planetary and Space Science, v. 56, p. 194-211.

Cutts, J.A., 1973, Wind erosion in the Martian polar regions: Journal of Geophysical Research, v. 78, no. 20, p. 42114221.

Cutts, J.A., Blasius, K.R., Briggs, G.A., Carr, M.H., Greeley, R., and Masursky, H., 1976, North polar region of Mars-Imaging results from Viking 2: Science, v. 194, p. 1329-1337.

Cutts, J.A., Blasius, K.R., and Roberts, W.J., 1979, Evolution of Martian polar landscapes - Interplay of long-term variations in perennial ice cover and dust storm intensity: Journal of Geophysical Research, v. 84, p. 2975-2994.

Cutts, J.A., and Lewis, B.H., 1982, Models of climate cycles recorded in Martian polar layered deposits: Icarus, v. 50, p. 216-244.

Dial, A.L., 1984, Geologic map of the Mare Boreum area of Mars: U.S. Geological Survey Miscellaneous Investigations Series I-1640, scale 1:5,000,000.
Dial, A.L., and Dohm, J.M., 1994, Geologic map of science study area 4, Chasma Boreale region of Mars: U.S. Geological Survey Miscellaneous Investigations Series Map I-2357, scale 1:500,000.

FGDC, 2006, FGDC Digital cartographic standard for geologic map symbolization: Reston, Va., prepared for the Federal Geographic Data Committee by the U.S. Geological Survey, Federal Geographic Data Committee (FGDC) Document Number FGDC-STD-013-2006, 307 p., 2 plates.

Fishbaugh, K.E., and Head, J.W., III, 2005, Origin and characteristics of the Mars north polar basal unit and implications for polar geologic history: Icarus, v. 174, p. 444- 474 (doi:10.1016/j.icarus.2004.06.021).

Fishbaugh, K.E., Hvidberg, C.S., Byrne, S., Russell, P.S., Herkenhoff, K.E., Winstrup, M., and Kirk, R., 2010, First high-resolution stratigraphic column of the Martian north polar layered deposits: Geophysical Research Letters, v. 37, no. L07201 (doi:10.1029/2009GL041642).

Greeley, R., and Batson, R.M., eds., 1990, Planetary mapping: Cambridge, U.K., Cambridge University Press, 296 p.

Hale, A.S., Bass, D.S., Tamppari, L.K., 2005, Monitoring the perennial martian northern polar cap with MGS MOC: Icarus, v. 174, p. 502-512.

Herkenhoff, K.E., 2001, Geologic map of the MTM-85000 quadrangle, Planum Australe region of Mars: U.S. Geological Survey Geologic Investigations Series I-2686, scale $1: 500,000$.

Herkenhoff, K.E., 2003, Geologic map of the MTM 85080 quadrangle, Chasma Boreale region of Mars: U.S. Geological Survey Geologic Investigations Series Map I-2753, scale 1:500,000.

Herkenhoff, K.E., Byrne, S., Russell, P.S., Fishbaugh, K.E., and McEwen, A.S., 2007, Meter-scale morphology of the north polar region of Mars: Science, v. 317, p. 1711-1715.

Herkenhoff, K.E., and Murray, B.C., 1990, Color and albedo of the south polar layered deposits on Mars: Journal of Geophysical Research, v. 95, p. 1343-1358.

Herkenhoff, K.E., and Plaut, J.J., 2000, Surface ages and resurfacing rates of the polar layered deposits on Mars: Icarus, v. 144 , no. 2 , p. 243-252.

Herkenhoff, K.E., Soderblom, L.A., and Kirk, R.L., 2002, MOC photoclinometry of the north polar residual cap on Mars [abs.], in Lunar and Planetary Science Conference, 33rd: Houston, Tex., Lunar and Planetary Institute, no. 1714 [CD-ROM].

Howard, A.D., 2000, The role of eolian processes in forming surface features of the Martian polar layered deposits: Icarus, v. 144, p. 267-288.

Howard, A.D., Cutts, J.A., and Blasius, K.R., 1982, Stratigraphic relationships within martian polar cap deposits: Icarus, v. 50, p. 161-215.

Kolb, E.J., and Tanaka, K.L., 2001, Geologic history of the polar regions of Mars based on Mars Global Surveyor Data, II-Amazonian period: Icarus, v. 154, p. 22-39.

Laskar, Jacques, Correia, A., Gastineau, M., Joutel, F., Levrard, Benjamin, and Robutel, P., 2004, Long term evolution and chaotic diffusion of the insolation quantities of Mars: Icarus, v. 170, p. 343-364. 
Laskar, J., Levrard, B., and Mustard, J.F., 2002, Orbital forcing of the martian polar layered deposits: Nature, v. 419, p. $375-377$.

Malin, M.C., and Edgett, K.S., 2001, Mars Global Surveyor Mars Orbiter Camera-Interplanetary cruise through primary mission: Journal of geophysical Research, v. 106, p. 23,429-23,520.

Milkovich, S.M., and Head, J.W., III, 2005, North polar map of Mars-Polar layered deposit characterization and identification of a fundamental climate signal: Journal of Geophysical Research, v. 110, no. E01005 (doi:10.1029/2004/ JE002349).

Murchie, S., and the CRISM Science Team, 2007, First results from the Compact Reconnaissance Imaging Spectrometer for Mars (CRISM) [abs.], in Lunar and Planetary Science Conference, 38th: The Woodlands, Tex., Lunar and Planetary Institute, no. 1472 [CD-ROM].

Ng, F.S.L., and Zuber, M.T., 2006, Patterning instability on the Mars polar ice caps: Journal of Geophysical Research, v. 111, no. E2, (doi: 10.1029/2005JE002533).

Phillips, R.J., Zuber, M.T., Smrekar, S.E., Mellon, M.T., and Head, J.W., 2008, Mars north polar deposits - Stratigraphy, age, and geodynamical response: Science, v. 320, p. 1182-1185.

Picardi, G., Plaut, J.J., Biccari, D., Bombaci, O., and Calabrese, D., 2005, Radar soundings of the subsurface of Mars: Science, v. 310, p. 1925-1928.

Rodriguez, J.A.P., Tanaka, K.L., Langevin, Y., Bourke, M.C., Kargel, J.S., Christensen, P.H., and Sasaki, Sho, 2007, Recent aeolian erosion and deposition in the north polar plateau of Mars: Mars Journal, v. 3, p. 29-41.

Scott, D.H., and Carr, M.H., 1978, Geologic map of Mars: U.S. Geological Survey Miscellaneous Investigations Series I-1083, scale 1:25,000,000.

Seidelmann, P.K., Abalakin, V.K., Bursa, M., and 8 others, 2002, Report of the IAU/IAG Working Group on Cartographic Coordinates and Rotational Elements of the Planets and Satellites - 2000: Celestial Mechanics and Dynamical Astronomy, v. 82, p. 83-110.

Smith, D.E., Zuber, M.T., Frey, H.V., Garvin, J.B., and Head, J.W., 2001, Mars Orbiter Laser Altimeter-Experiment summary after the first year of global mapping of Mars: Journal of Geophysical Research, v. 1056, p. 23,689-
23,722 .

Smith, I.B., and Holt, J.W., 2010, Onset and migration of spiral troughs on Mars revealed by orbital radar: Nature, v. 465, p. 40-453. (doi: 10.1038/nature09049).

Tanaka, K.L., 1986, The stratigraphy of Mars, in Proceedings of the Lunar and Planetary Science Conference, 17th, Part 1, November, 1986: Journal of Geophysical Research, v. 91, supplement no. B13, p. E139-158.

Tanaka, K.L., 2005, Geology and insolation-driven climatic history of Amazonian north polar materials on Mars: Nature, v. 437, no. 13 (doi:10.1038/nature04065).

Tanaka, K.L., and Fortezzo, C.M., 2012, Geologic map of the North Polar Regions of Mars: U.S. Geological Survey Scientific Investigations Map 3177, scale 1:2,000,000.

Tanaka, K.L., Rodriguez, J.A.P., Skinner J.A., Jr., Bourke, M.C., and Fortezzo, C.M., 2008, North polar region of MarsAdvances in stratigraphy, structure, and erosional modification: Icarus, v. 196, p. 318-358.

Tanaka, K.L., and Scott, D.H., 1987, Geologic map of the polar regions of Mars: U.S. Geological Survey Miscellaneous Investigations Series Map I-1802-C, scale 1:15,000,000.

Tanaka, K.L., Skinner, J.A., Jr., and Hare, T.M., 2005, Geologic map of the northern plains of Mars: U.S. Geological Survey Scientific Investigations Map 2888, scale $1: 15,000,000$.

Tanaka, K.L., Skinner, J.A., Jr., Hare, T.M., Joyal, T., and Wenker, A., 2003, Resurfacing history of the northern plains of Mars based on geologic mapping of Mars Global Surveyor data: Journal of Geophysical Research, v. 108, no. E2, (doi:10.1029/2002JE001908).

Thomas, P.C., Malin, M.C., Edgett, K.S., Carr, M.H., and Hartmann, W.K., 2000, North-south geological differences between the residual polar caps on Mars: Nature, v. 404, p. 161-164.

Titus, T.N., Calvin, W.M., Kieffer, H.H., Langevin, Y., and Prettyman, T.H., 2008, Martian polar processes, in Bell, J.F., ed., The martian surface - Composition, mineralogy, and physical properties: Cambridge, U.K., Cambridge University Press, 578 p.

Zuber, M.T., Smith, D.E., Solomon, S.C., Abshire, J.B., and 17 others, 1998, Observations of the north polar region of Mars from the Mars Orbiter laser altimeter: Science, v. 282, p. 2053-2060. 
Table 1. Relative age determinations for geologic units in the Olympia Rupēs region of Mars.

\begin{tabular}{|c|c|c|c|c|c|}
\hline $\begin{array}{l}\text { Geographic } \\
\text { region }\end{array}$ & $\begin{array}{l}\text { Unit } \\
\text { name }\end{array}$ & $\begin{array}{l}\text { Unit } \\
\text { label }\end{array}$ & $\begin{array}{l}\text { Relative } \\
\text { age }^{1}\end{array}$ & $\begin{array}{c}\text { Area }^{2} \\
\left(10^{3} \mathrm{~km}^{2}\right)\end{array}$ & $\begin{array}{l}\text { Superposition } \\
\text { relations }^{3}\end{array}$ \\
\hline Boreum & Boreum 3 unit & $\mathrm{Ab}_{3}$ & LA & 38.78 & $<$ Aou, $A o c_{3}, A b_{2}, A o c_{2}, A b_{1}, \sim A o u$ \\
\hline Olympia & Olympia Undae unit & Aou & LA & 6.57 & $>A b_{3}, \sim A b_{3}, A o c_{3}, A b_{2}, A o c_{2},<A b_{1}, A o c_{1}$ \\
\hline Olympia & Olympia Cavi 3 unit & $\mathrm{Aoc}_{3}$ & LA & 1.10 & $>\mathrm{Ab}_{3}, \sim \mathrm{Aou}, \mathrm{Ab}_{2},<\mathrm{Aou}, \mathrm{Ab}_{2}, \mathrm{Aoc}_{2}, \mathrm{Ab}_{1}, \mathrm{Aoc}_{1}$ \\
\hline Boreum & Boreum 2 unit & $\mathrm{Ab}_{2}$ & LA & 11.66 & $>\mathrm{Ab}_{3}, \mathrm{Aou}, \mathrm{Aoc}_{3}, \sim \mathrm{Aou}, \mathrm{Aoc}_{3},<\mathrm{Aoc}_{2}, \mathrm{Ab}_{1}, \mathrm{Aoc}_{1}$ \\
\hline Olympia & Olympia Cavi 2 unit & $\mathrm{Aoc}_{2}$ & MA-LA (?) & 1.11 & $>\mathrm{Ab}_{3}, \mathrm{Aou}, \mathrm{Aoc}_{3}, \mathrm{Ab}_{2}, \sim \mathrm{Aou},<\mathrm{Ab}_{1}, \mathrm{Aoc}_{1}$ \\
\hline Boreum & Boreum 1 unit & $A b_{1}$ & MA-LA (?) & 3.67 & $>\mathrm{Ab}_{3}, \mathrm{Aou}, \mathrm{Aoc}_{3}, \mathrm{Ab}_{2}, \mathrm{Aoc}_{2},<\mathrm{Aoc}_{1}$ \\
\hline Olympia & Olympia Cavi 1 unit & Aoc $_{1}$ & MA & 1.11 & $>\mathrm{Ab}_{3}, \mathrm{Aou}, \mathrm{Aoc}_{3}, \mathrm{Ab}_{2}, \mathrm{Aoc}_{2}, \mathrm{Ab}_{1}$ \\
\hline
\end{tabular}

${ }_{1}^{1}$ Relative age determined by superposition relations only: LA, Late Amazonian; MA, Middle Amazonian (after Tanaka, 1986).

${ }^{2}$ Area includes exposed area of unit only.

${ }^{3}$ Symbols: $<$, younger than; $\sim$, overlaps in time with; >, older than.

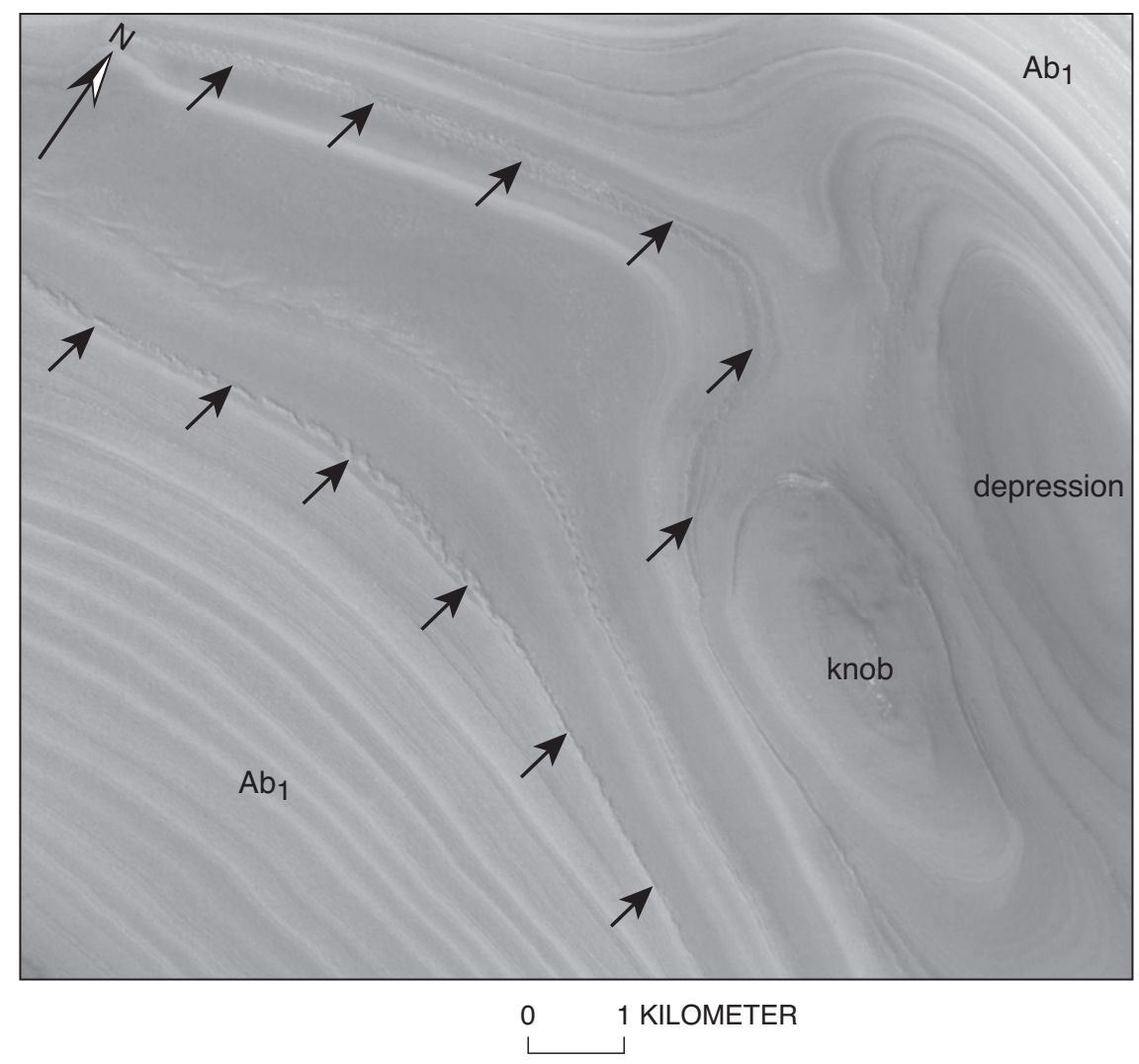

Figure 2. Excerpt of CTX image number P01_001341_2654 (centered at lat $85.21^{\circ}$ N., long $147.19^{\circ}$ E.; location shown on map) that shows local geomorphology that occurs within the Planum Boreum 1 unit $\left(A b_{1}\right)$. These include berms (denoted by black arrows), as well as a knob and depression. 


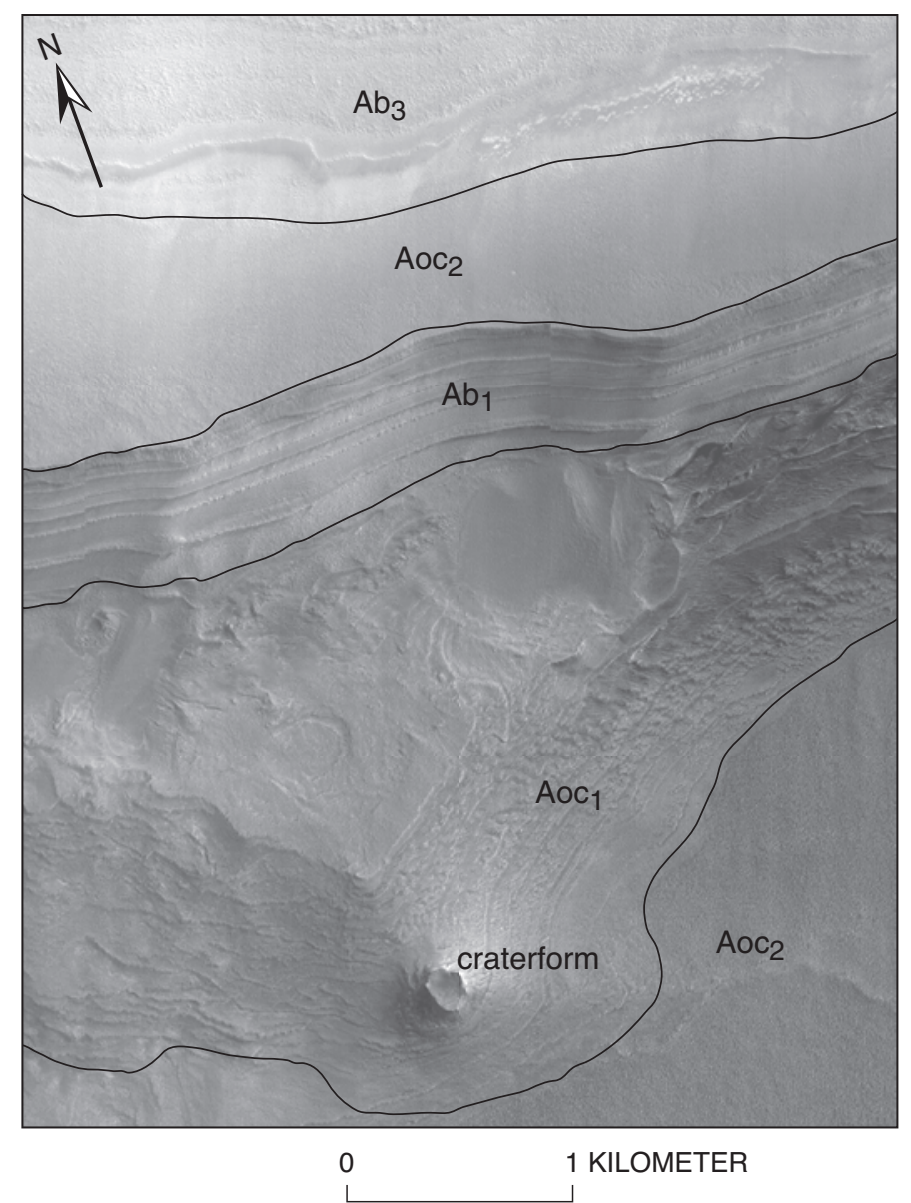

Figure 3. Excerpt of High Resolution Imaging Science Experiment image number PSP 001548-2755 (centered at lat $84.39^{\circ} \mathrm{N}$., long $142.94^{\circ} \mathrm{E}$.; location shown on map) that shows a scarp-exposed section of layered deposits south of the Olympia Rupēs. Vertical section is $\sim 400 \mathrm{~m}$ thick within the image excerpt. Sinuous high- and low-albedo layers define the margin of the Planum Boreum 3 unit $\left(A b_{3}\right)$, which buries Olympia Cavi 2 unit $\left(\mathrm{Aoc}_{2}\right)$ above the scarp. Unit $\mathrm{Aoc}_{1}$ forms a medium-albedo, smooth surface above the rhythmic layering of the Planum Boreum 1 unit $\left(A b_{1}\right)$. A craterform feature, crater A ( $\sim 150 \mathrm{~m}$ diameter), interpreted as the eroded vestige of an impact crater, resides in the Olympia Cavi 1 unit $\left(\right.$ Aoc $\left._{1}\right)$.

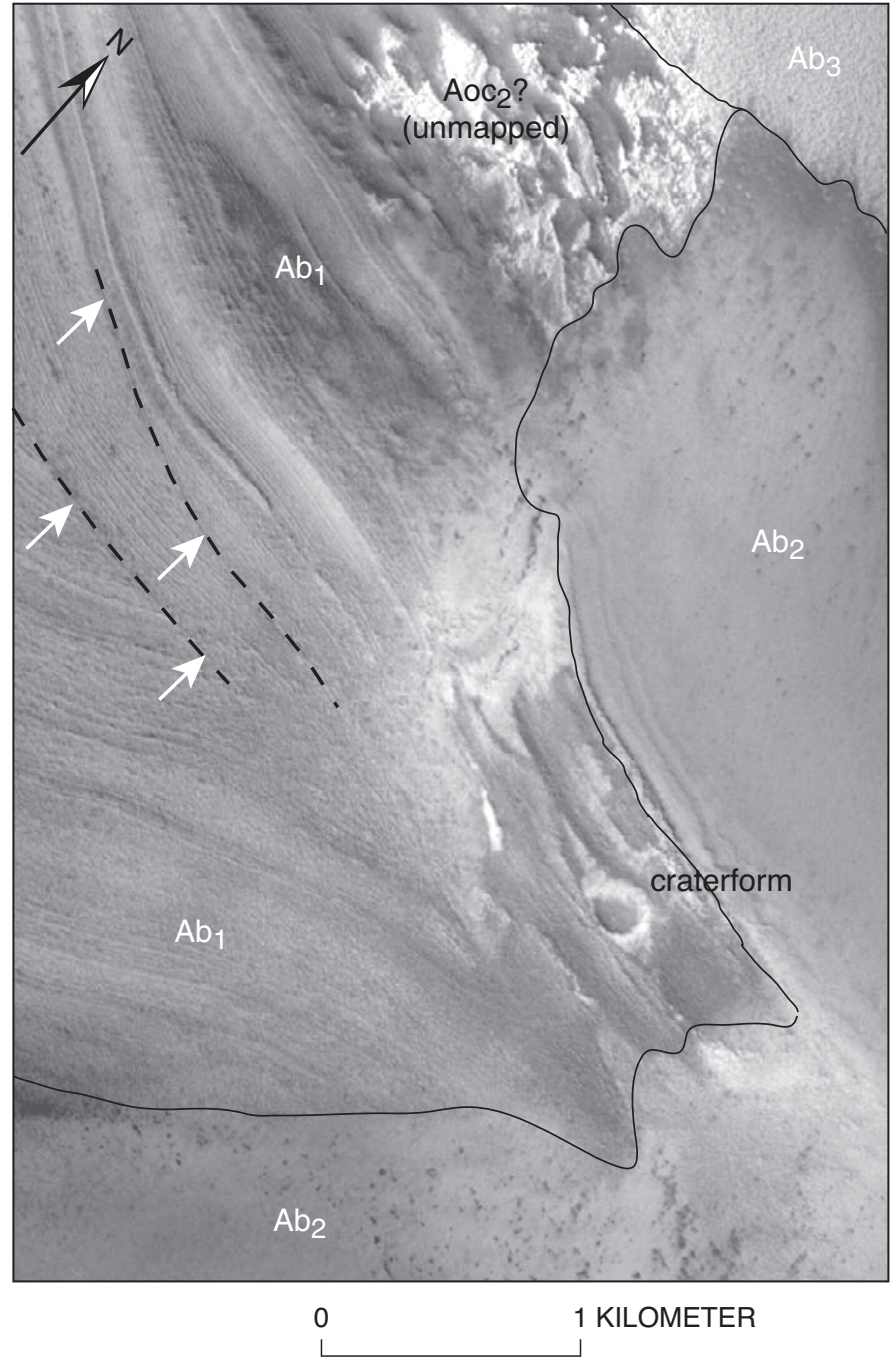

Figure 4. Excerpt of Mars Orbiter Camera narrow-angle image number e03-02719 (centered at lat $85.14^{\circ} \mathrm{N}$., long $168.76^{\circ} \mathrm{E}$.; location shown on map) that shows unit relations near the eastern termination of a polar trough, south of the Olympia Rupēs. Excerpt is centered near a craterform feature, crater B, in the Planum Boreum 1 unit $\left(A b_{1}\right)$. Two subparallel angular truncations (unconformities) are visible in the unit $A b_{1}$ (white arrows). Uppermost sequences of unit $A b_{1}$ are locally overlain by Planum Boreum 2 and 3 units $\left(A b_{2}, A b_{3}\right)$, demonstrating the unconformable nature of the polar layered sequences. Though it is not visible at map scale, the massive, darker material that underlies high-albedo patches of the Planum Boreum 3 unit located at top center may be a small outcrop of the Olympia Cavi 2 unit $\left(\mathrm{Aoc}_{2}\right.$ ?). 


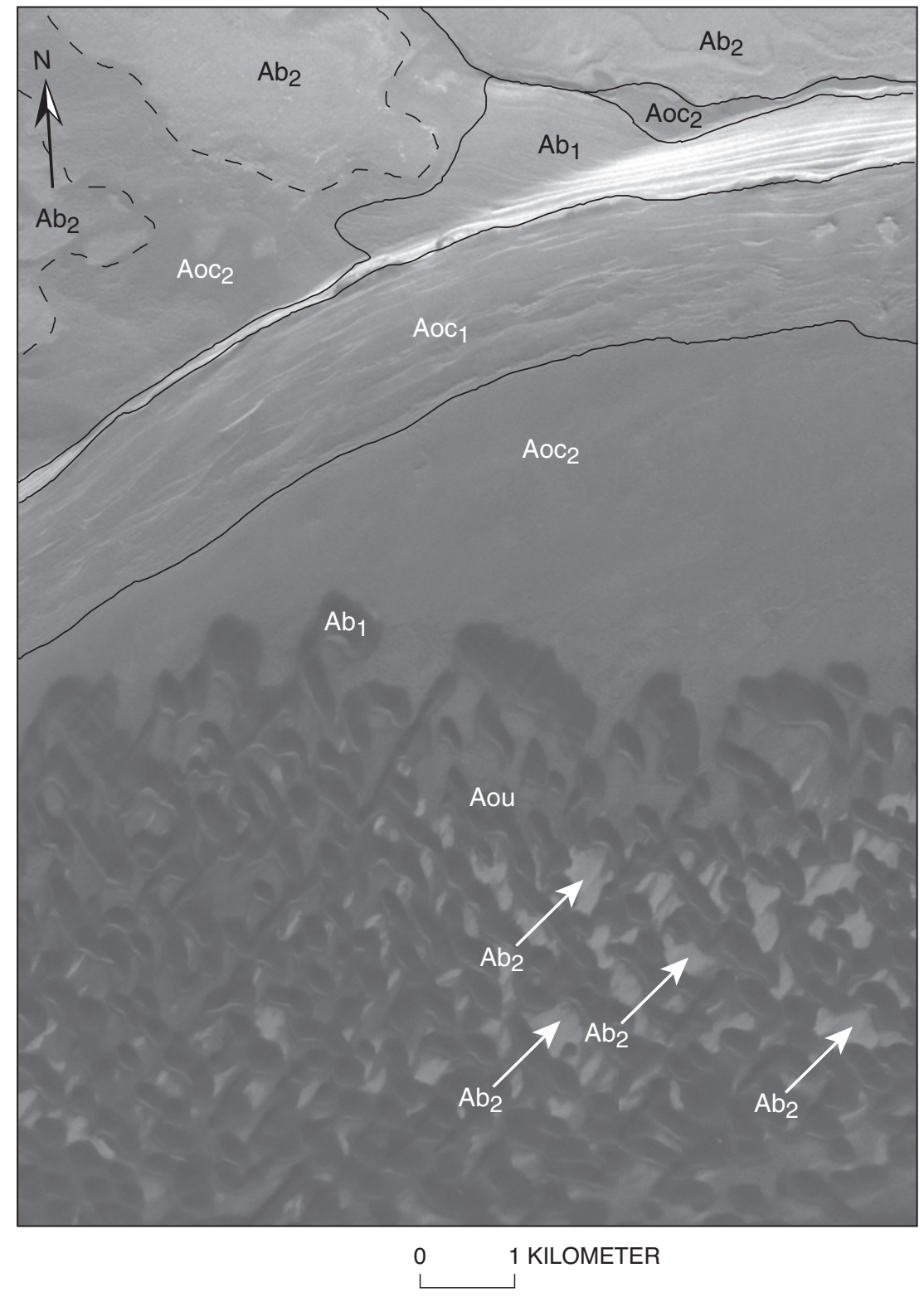

Figure 5. Excerpt of Context Imager (CTX) image number P02_001670_2643 (centered at lat $84.94^{\circ}$ N., long $176.56^{\circ}$ E.; location shown on map) that shows the margin of a scarp-exposed section of the Olympia Cavi 1 and Planum Boreum 1 units $\left(A_{o c} 1\right.$ and $\left.A b_{1}\right)$ along Olympia Rupēs. The Olympia Cavi 2 unit $\left(A_{0} c_{2}\right)$ resides both above and below the scarp. The scarp wall is made up of unit $A_{2} c_{1}$, which is interpreted to extend beneath younger units to underpin the exposed cavi floor materials. The Planum Boreum 2 unit $\left(A b_{2}\right)$, though locally unmapped, can be seen as high-albedo patches (white arrows) beneath the Olympia Undae unit (Aou), both of which overlie unit Aoc2. 